\title{
Cellular immunity in systemic lupus erythematosus as evidenced in vitro by leucocyte migration inhibition test
}

\author{
MICHIHITO OKUBO, YUJI NAGURA, ${ }^{*}$ DOMINIC POMPA, \\ GERHARD TRESER, AND KURT LANGE \\ From the Renal Service and Laboratory, Department of Medicine, New York Medical College and New York \\ Metropolitan Hospital Center, New York
}

\begin{abstract}
SUMMARY A leucocyte migration inhibition test was performed on 26 patients with systemic lupus erythematosus (SLE) and on 35 control subjects using three different antigens, fetal calf thymus DNA, baker's yeast RNA, and calf thymus extractable nuclear antigen (ENA). Leucocyte migration was inhibited by DNA in 17 out of 26 SLE patients $(65.3 \%$ ), and in only 2 of the 35 controls $(5.7 \%)$. When RNA or ENA was added none of the patients or controls showed inhibition. In SLE patients migration inhibition by DNA was significantly correlated with the presence of proteinuria and/or granular casts in urinary sediment. When the migration inhibition test was positive, immunofluorescence verified active histology of the glomeruli obtained by a percutaneous renal biopsy.
\end{abstract}

Humoral immunity in the pathogenesis of systemic lupus erythematosus (SLE) has been well documented, but the role of cell-mediated immunity has yet to be thoroughly investigated. Although it is still a matter for debate, several workers (Bitter et al., 1971; Federlin and Helmke, 1972; Horwitz, 1972; Messner et al., 1973; Williams et al., 1973) have found depressed cellular immunity in active SLE. Goldman et al. (1972), studying patients with lupus nephritis, reported a stimulatory effect by native DNA in lymphocytes cultured in vitro, and Abe et al. (1973) observed the macrophage migration inhibition factor to DNA in vitro in their study of patients with SLE and the nephrotic syndrome.

To further evaluate the possible role of delayed hypersensitivity to DNA in the pathogenesis of SLE nephritis, leucocyte migration inhibition tests were performed on our patients using calf thymus DNA as antigen. The results were analysed together with the immunohistological study of kidney biopsy specimens obtained simultaneously.

Accepted for publication February 22, 1977

Correspondence to Dr. M. Okubo, Department of Medicine, Kitasato University, School of Medicine, 1 Asamizo-dai, Sagamihara-shi, Kanagawa-ken, Japan.

*Present address: Department of Medicine, Nihon University, School of Medicine, 30 Oyaguchi-kami-machi, Itabashiku, Tokyo, Japan.

\section{Patients and methods}

Twenty-six SLE cases (Table 1) were diagnosed according to the ARA criteria (Cohen et al., 1971). All had 'definite' SLE, exhibiting four or more manifestations plus the presence of a positive LE preparation and/or anti-DNA antibody. Kidney biopsies were performed on 22 patients. 23 normal subjects and 22 patients with other diseases served as the controls (Table 2).

COMPLEMENT $\left(\mathrm{CH}_{50}\right)$

Levels were determined according to the method described previously using $50 \%$ haemo'ysis as the end-point (Lange et al., 1960).

DNA

DNA used for the haemagglutination test was prepared by the method of Kay et al. (1952), using quick-frozen calf thymus. The procedure was stopped at step 7. The amount of protein measured using the method of Lowry et al. (1951) was found to be insignificant.

A haemagglutination test for DNA antibody was performed using a modified version of the method of Sharp et al. (1971). Tanned human type $O$ erythrocytes were used for agglutination instead of sheep red blood cells (R. J. Winchester, personal communication, 1974). LE cell preparations were 
Table 1 Migration inhibition index in patients with SLE

\begin{tabular}{|c|c|c|c|c|c|c|c|c|c|}
\hline \multirow{2}{*}{$\begin{array}{l}\text { Case } \\
\text { no. }\end{array}$} & \multirow{2}{*}{$\begin{array}{l}\text { Age } \\
\text { (yrs) }\end{array}$} & \multirow[t]{2}{*}{ Sex } & \multirow{2}{*}{$\begin{array}{l}\text { Duration } \\
\text { of } S L E \\
\text { (yrs) }\end{array}$} & \multirow[t]{2}{*}{ Outcome } & \multicolumn{4}{|c|}{ Migration inhibition index } & $\overrightarrow{\vec{B}}$ \\
\hline & & & & & $\begin{array}{l}P P D \\
20 \mu \mathrm{g} / \mathrm{ml} \\
(\%)\end{array}$ & $\begin{array}{l}\text { DNA } \\
200 \mu \mathrm{g} / \mathrm{ml} \\
(\%)\end{array}$ & $\begin{array}{l}\text { RNA } \\
500 \mu \mathrm{g} / \mathrm{ml} \\
(\%)\end{array}$ & $\begin{array}{l}E N A \\
2400 \mu \\
(\%)\end{array}$ & 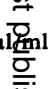 \\
\hline 1 & 46 & $\mathbf{F}$ & 5 & Alive & 70 & $74,70,99,95$ & 87 & 123 & ग \\
\hline 2 & 19 & $\mathbf{F}$ & 5 & ," & 63,132 & $60,95,115,94$ & 103 & & ○ \\
\hline 3 & 42 & $\mathbf{F}$ & 9 & ", & & 61,77 & & & 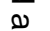 \\
\hline 4 & 20 & $\mathbf{F}$ & 6 & , & & 67,64 & & 90 & $\omega$ \\
\hline 5 & 35 & $\mathbf{F}$ & 5 & ", & & 73,69 & & & $\vec{\nabla}$ \\
\hline 6 & 36 & $\mathbf{F}$ & 3 & ", & & $21,59,67,80,91$ & 85 & & . \\
\hline 7 & 17 & $\mathbf{M}$ & 10 & $"$ & & 64,88 & 99 & & $\vec{z}$ \\
\hline 8 & 20 & $\mathbf{M}$ & $9 \mathrm{~m}$ & ", & & $61,75,107$ & & & $\vec{\omega}$ \\
\hline 9 & 16 & $\mathbf{F}$ & 3 & ", & 89 & 55,125 & & & の \\
\hline 10 & 23 & $\mathbf{F}$ & 8 & ," & 55 & $77,67,35,111,78$ & & & 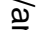 \\
\hline 11 & 31 & $\mathbf{F}$ & 2 & ," & & 97,61 & & & $\bar{\alpha}$ \\
\hline 12 & 80 & $\mathbf{F}$ & & Died & & 55 & & & $\bar{\omega}$ \\
\hline 13 & 18 & $\mathbf{F}$ & 1 & Alive & & $68,100,68$ & & & గ్రి \\
\hline 14 & 31 & $\mathbf{M}$ & 2 & , & & $91,91,76,69$ & 97 & & ن \\
\hline 15 & 30 & $\mathbf{F}$ & 1 & ", & & 80,72 & & & is \\
\hline 16 & 36 & $\mathbf{F}$ & & Died & & 95,69 & & 94 & 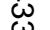 \\
\hline 17 & 40 & $\mathbf{F}$ & 2 & Alive & & 68,104 & & 97,85 & 5 \\
\hline 18 & 27 & $\mathbf{F}$ & 3 & ", & 106 & $83,90,80$ & & & 윽 \\
\hline 19 & 26 & $\mathbf{F}$ & 1 & $"$ & & 78,78 & & & $=$ \\
\hline 20 & 25 & $\mathbf{F}$ & 11 & $"$ & & 93,100 & & & $\overrightarrow{0}$ \\
\hline 21 & 20 & $\mathbf{F}$ & & ", & & 98,95 & & & O \\
\hline 22 & 30 & $\mathbf{F}$ & 11 & $"$ & & 81 & & & $\frac{11}{0}$ \\
\hline 23 & 31 & $\mathbf{M}$ & 4 & $"$ & 81 & 100,113 & 86 & & O \\
\hline 24 & 35 & $\mathrm{~F}$ & 3 & ", & & 102,97 & 87 & & $\underline{\Phi}$ \\
\hline 25 & 21 & $\mathbf{F}$ & 9 & $"$ & & 86,95 & & & $\rightarrow$ \\
\hline 26 & 54 & $\mathbf{F}$ & 4 & ", & & 113 & & & $\overrightarrow{0}$ \\
\hline
\end{tabular}

made by the 2-hour blood clot technique (Hargraves et al., 1948).

\section{LEUCOCYTE MIGRATION INHIBITION TEST (MIT)}

\section{Tuberculin PPD}

Materials without preservatives were purchased from Parke-Davis (Detroit, Mich.). $20 \mu \mathrm{g} / \mathrm{ml}$ was in the culture medium.

\section{DNA}

Commercially available fetal calf thymus DNA was obtained from Worthington Chemicals (Freehold, N.J.). Over $90 \%$ of the lyophilized material was composed of double-stranded DNA. $200 \mu \mathrm{g} / \mathrm{ml}$ DNA was used in the culture medium.

$R N A$

Baker's yeast RNA was purchased from Worthington Chemicals and was used in a concentration of $500 \mu \mathrm{g} / \mathrm{ml}$.

\section{Extractable nuclear antigen (ENA)}

Prepared according to the method of Sharp et al. (1972). A concentration of $2400 \mu \mathrm{g} / \mathrm{ml}$ was used.

The MIT was performed according to the method of Søborg and Bendixen (1967) with some modifications. $20 \mathrm{ml}$ peripheral blood was drawn into a disposable plastic syringe containing 2000 units heparin (Lipohepin, Riker, Northridge, Calif.), held upright for 60 to 90 minutes in a $37^{\circ} \mathrm{C}$ incubator 90 obtain leucocyte-rich plasma (buffy coat). The plasma plus the same volume of normal saline ware mixed in a sterilized $15 \mathrm{ml}$ test tube, centrifugedmat $400 \mathrm{~g}$ for 10 minutes, then the supernatant was discarded by aspiration. After adding Ringe lactate, the sediment was washed twice by centrifugation at $400 \mathrm{~g}$ for 5 minutes. The WBC cought, differential count, and Trypan-blue exclusion test for viability were performed. The cell pellet obtained was resuspended in a Ringer's lactate solution having a concentration of $20 \times 10^{6}$ monnuclear cells $/ \mathrm{ml}$.

The cell suspension was put into capillary tubes (inner diameter 1.1-1.2 mm), one end sealed with clay, then centrifuged at $400 \mathrm{~g}$ for 5 minutes. Th cell column which formed at the bottom was at the supernatant-cell interphase, and put intio a McKanes plastic chamber (Univers Mekaniska Verkstad AB Herrhagsv, 98 Endkede, Swedent, affixing the closed end to side-wall of the chamber with stop-cock grease. The chamber was filled with TC Medium 199 (Difco, Detroit, Mich.) containing $100 \mathrm{U} / \mathrm{ml}$ penicillin, $100 \mu \mathrm{g} / \mathrm{ml}$ streptomycin, aInd $20 \%$ fetal calf serum (heat-inactivated, Flow LaD. Rockville, M.D.). pH was preadjusted to $7 \cdot 4$ with $8 \% \mathrm{NaHCO}_{3}$.

Triplicate cultures were set up for each antigen and additional triplicate chambers containing te same volume of Ringer's lactate as that of the 
Table 2 Migration inhibition index in normal controls and in patients with other diseases

\begin{tabular}{|c|c|c|c|c|c|c|c|}
\hline \multirow{2}{*}{$\begin{array}{l}\text { Case } \\
\text { no. }\end{array}$} & \multirow{2}{*}{$\begin{array}{l}\text { Age } \\
\text { (yrs) }\end{array}$} & \multirow[t]{2}{*}{ Sex } & \multirow[t]{2}{*}{ Clinical diagnosis } & \multicolumn{4}{|c|}{ Migration inhibition index } \\
\hline & & & & $\begin{array}{l}P P D \\
20 \mu \mathrm{g} / \mathrm{ml} \\
(\%)\end{array}$ & $\begin{array}{l}\text { DNA } \\
200 \mu \mathrm{g} / \mathrm{ml} \\
(\%)\end{array}$ & $\begin{array}{l}R N A \\
500 \mu \mathrm{g} / \mathrm{ml} \\
(\%)\end{array}$ & $\begin{array}{l}E N A \\
2400 \mu \mathrm{g} / \mathrm{ml} \\
(\%)\end{array}$ \\
\hline \multicolumn{8}{|c|}{ Normal controls } \\
\hline 27 & 30 & $\mathbf{M}$ & Healthy & & 84,95 & & 187 \\
\hline 28 & 37 & $\mathbf{M}$ & ", & & 74,83 & & 101 \\
\hline 29 & 36 & $\mathbf{M}$ & $"$ & & 117 & & \\
\hline 30 & 37 & $\mathbf{M}$ & ", & 73 & 85,83 & & \\
\hline 31 & 31 & $\mathbf{M}$ & $"$ & 84,108 & 79 & & \\
\hline 32 & 23 & $\mathbf{F}$ & $"$, & 105 & 92 & 108 & \\
\hline 33 & 38 & $\mathbf{M}$ & ", & & 77 & 105 & \\
\hline 34 & 45 & $\mathbf{M}$ & ", & & 106 & 105 & \\
\hline 35 & 24 & $\mathbf{F}$ & , & 108 & 91 & 101 & \\
\hline 36 & 33 & $\mathbf{M}$ & ", & & 79 & 97 & \\
\hline 37 & 25 & $\mathbf{M}$ & , & & 106 & 129 & \\
\hline 38 & 37 & $\mathbf{M}$ & ", & & 110 & 74 & \\
\hline 39 & 34 & $\mathbf{F}$ & ," & & 90 & 100 & \\
\hline 40 & 28 & $\mathbf{F}$ & , & 107 & $60,84,86$ & 122 & \\
\hline 41 & 42 & $\mathbf{M}$ & , & & 104 & 137 & \\
\hline 42 & 30 & $\mathbf{F}$ & " & & 108 & & \\
\hline 43 & 28 & $\mathbf{F}$ & $"$ & & 86 & & \\
\hline 44 & 26 & $\mathrm{~F}$ & $"$ & & 93 & & \\
\hline 45 & 20 & $\mathbf{F}$ & ", & & 114 & & \\
\hline 46 & 30 & $\mathbf{M}$ & ", & & & 107 & \\
\hline 47 & 30 & $\mathbf{F}$ & ", & 63 & & & \\
\hline 48 & 28 & $\mathbf{M}$ & $"$ & 94 & & & \\
\hline 49 & 31 & $\mathbf{F}$ & $"$ & 94 & & & \\
\hline \multicolumn{8}{|c|}{ Patients with other diseases } \\
\hline 50 & 22 & $\mathbf{F}$ & $\begin{array}{l}\text { Acute-poststreptococcal } \\
\text { glomerulonephritis; }\end{array}$ & & 110 & & \\
\hline 51 & 19 & $\mathbf{F}$ & Rheumatoid arthritis & & 101 & & \\
\hline 52 & 24 & $\mathbf{F}$ & Orthostatic proteinuria & & 108 & & \\
\hline 53 & 30 & $\mathrm{~F}$ & Rheumatoid arthritis & & 120 & & \\
\hline 54 & 18 & $\mathbf{F}$ & Rheumatic heart disease & & 85 & 74 & \\
\hline 55 & 20 & $\mathbf{M}$ & Nephrotic syndrome & & 93 & 103 & \\
\hline 56 & 25 & $\mathbf{F}$ & Arthritis & & 99 & & \\
\hline 57 & 40 & $\mathbf{M}$ & Diabetes mellitus & & 84 & 95 & \\
\hline 58 & 43 & $\mathbf{F}$ & Obesity & & 103 & 95 & \\
\hline 59 & 31 & $\mathbf{M}$ & Anaemia & & 90 & & \\
\hline 60 & 17 & $\mathrm{~F}$ & Factor 7 deficiency anaemia & & 94 & & \\
\hline 61 & 27 & $\mathbf{F}$ & Chronic active hepatitis & & 95 & & \\
\hline 62 & 21 & $\mathbf{M}$ & Nephrotic syndrome & & 100,92 & & \\
\hline 63 & 25 & $\mathbf{M}$ & Nephrotic syndrome & & 124 & & \\
\hline 64 & 43 & $\mathbf{F}$ & Chronic active hepatitis & & 101 & & \\
\hline 65 & 45 & $\mathbf{F}$ & Sarcoidosis & & 90 & & \\
\hline 66 & 50 & $\mathbf{M}$ & Tuberculosis & 43 & & & \\
\hline 67 & 42 & $\mathbf{M}$ & , & 44 & & & \\
\hline 68 & 27 & $\mathbf{M}$ & ," & 58,68 & & & \\
\hline 69 & 61 & $\mathbf{M}$ & $"$ & 50 & & & \\
\hline 70 & 25 & $\mathbf{M}$ & , & 40 & & & \\
\hline 71 & 22 & $\mathbf{M}$ & Hereditary nephritis & 82 & & & \\
\hline
\end{tabular}

antigen served as the control. Each chamber was put in a $37^{\circ} \mathrm{C} \mathrm{CO}$-incubator for 21 hours. A photoenlarger was used to draw the migratory area on paper. The image was cut out, weighed, and the migration inhibition index (MII) calculated as

$\frac{\mathrm{mg} \text { image of chamber with antigen }}{\mathrm{mg} \text { image of chamber without antigen }} \times 100(\%)$.

Considering that the mean -1 standard deviation of the MII with DNA was found to be $92 \%-15 \cdot 5$ (76.5\%) for 19 normal controls (Table 2, Fig. 2), an MII of $<75 \%$ was arbitrarily chosen to represent inhibition. Sterile technique was kept throughout the culture procedure.

\section{PREPARATION AND EXAMINATION OF KIDNEY TISSUE}

Kidney biopsy specimens for light microscopy were fixed in $10 \%$ neutral formalin and embedded in paraffin. 2-3 $\mu \mathrm{m}$ thick sections were stained with a haematoxylin-eosin, periodic acid schiff (PAS), and periodic acid silver methenamine.

Specimens for immunohistology were prepared by immediately embedding the biopsy cylinder in fresh rat liver and freezing for 3 minutes in an 
isopentane-dry ice mixture (Lange et al., 1966). $3 \mu \mathrm{m}$ thick sections were sliced on a $-20^{\circ} \mathrm{C}$ cryostat, air dried, stained with FITC-labelled sera (Sober $e t$ al., 1956; Riggs et al., 1960) for 30 minutes in a moist chamber, and washed in $0.01 \mathrm{M}$ phosphatebuffered saline $\mathrm{pH} 7 \cdot 1$. They were examined under a Leitz ultraviolet microscope with a $200 \mathrm{~W}$ Osram B high tension mercury vapour bulb and photographed with a Leitz Orthomat camera using Anscochrome 200 outdoor film.

Specimens for electron microscopy were fixed in $1 \%$ osmium tetroxide, dehydrated in graded ethanol, and embedded in epon. Ultrathin sections were prepared on a Reichert II microtome. Sections were stained with uranyl acetate and lead citrate, then examined under a Hitachi HU-11A electron microscope.

\section{Results}

\section{PRELIMINARY STUDIES}

In order to verify that MIT can be a good parameter of cellular immunity, a skin test for tuberculin PPD was simultaneously performed on 13 subjects (Fig. 1). The mean \pm 1 SD of the MII $(53 \% \pm 12 \cdot 1)$ for the subjects with positive skin tests was found to be

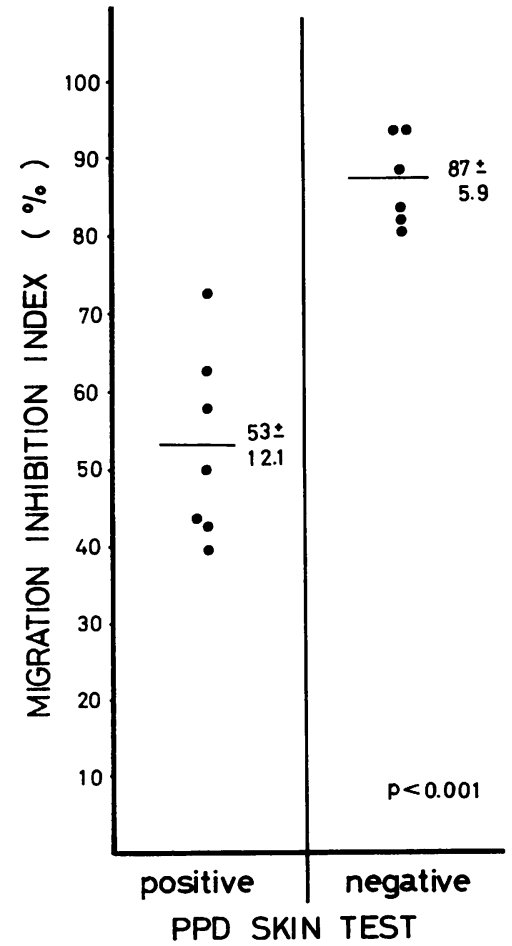

Fig. 1 Migration inhibition test with tuberculin PPD as antigen and skin test with the same antigen. significantly lower than that $(87 \% \pm 5.9)$ af subjects with negative skin tests $(P<0.001)$. Thfe mean \pm 1 SD $(51 \% \pm 10 \cdot 7)$ for the tuberculou $\overrightarrow{5}$ cases was significantly different from that of the $?$ SLE patients $(85 \% \pm 26 \cdot 7)$ and 9 normal sul jects $(93 \% \pm 16.5) \quad\left(P<0.02\right.$ and $P<0.00 \frac{E}{5}$ respectively).

The MIT with DNA antigen was performed of 26 SLE patients, 17 of them $(65.3 \%)$ showing inhibition at some time during the course of the illness, with a mean ( $\pm 1 \mathrm{SD})$ MII* of $71 \% \pm 19: 7$ (Table 1, Fig. 2). In the 35 controls, comprised $\overrightarrow{\sigma f}$ 19 normal subjects and 16 patients with others diseases (Table 2, Fig. 2), no migration inhibition was observed except in 2 normal subjects (Cases 28 40, Table 2) who showed inhibition with MII titrès of $74 \%$ and $60 \%$, respectively. The mean of thes MII titre in the SLE subjects was significantFy

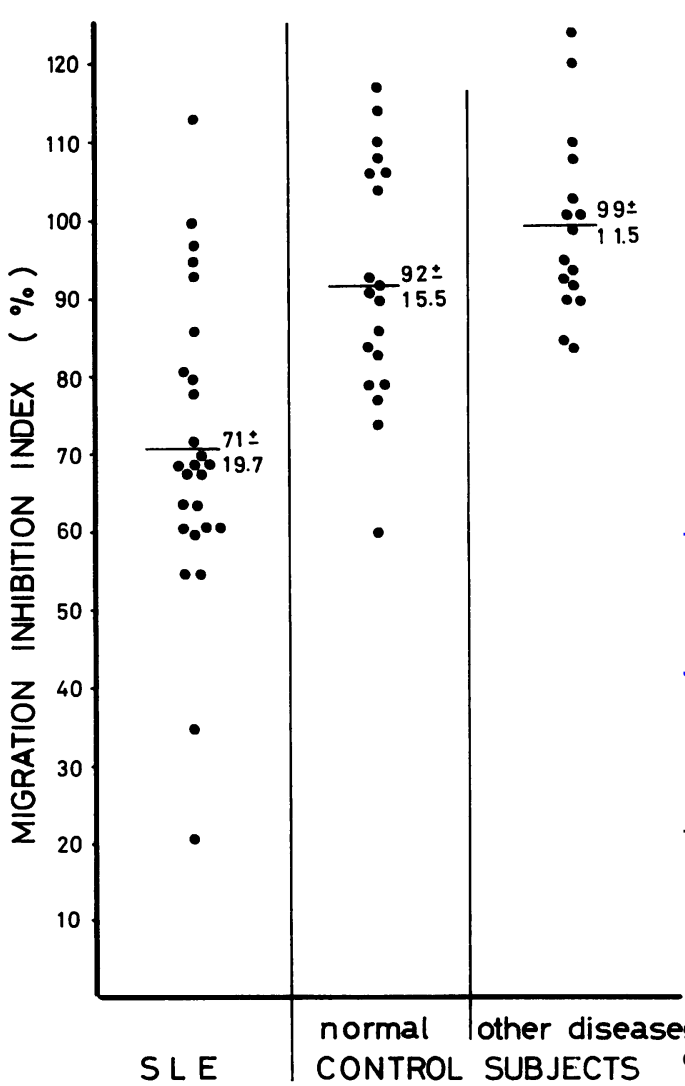

Fig. 2 Migration inhibition test with DNA as antigen patients with SLE and in control subjects.

*Each subject, either patient or control, was represented bi⿱ the minimal MII titre when MIT was done two or mo times. 
lower than that in the control subjects as a whole $(96 \% \pm 14 \cdot 1) \quad(P<0.001)$. The difference in mean values between the SLE patients $(71 \% \pm$ $19 \cdot 7)$ and the normal controls $(92 \% \pm 15.5)$ or that between SLE patients and patients with other diseases $(99 \% \pm 11.5)$ was also significant $(\mathrm{P}<0.001$ in both cases; Fig. 2, Tables 1, 2), while the difference in mean values between normals and patients with other diseases was nonsignificant $(\mathbf{P}<0 \cdot 1$; Fig. 2, Table 2). Of the 2 normal subjects whose MIT showed inhibition, the one with the borderline test (Case 28, 74\%, Table 2) was found to have a normal MII $(83 \%)$ at the second estimation. The other with an MII titre of $60 \%$ (Case 40, Table 2) was a female doctor with a past history of unexplained leucopenia and a family history of a lymphoproliferative disorder.

The results of the MIT with DNA as antigen in SLE patients did not correlate significantly with flever, erythema, arthralgia, and/or Raynaud's phenomenon, or values of ESR, WBC, Coombs's test, LE cells, anti-DNA antibody, or complement $(P>0.05)$. However, the mean MII in symptomatic patients with positive laboratory tests tended to be higher than the mean of the asymptomatic patients. A few individual cases showed good correlation between the MII titre and the presence of signs, symptoms, and positive laboratory tests. One representative case follows.

\section{Case 8 (Fig. 3, Table 1)}

A 20-year-old Chinese male student, admitted with a fever of $37.8^{\circ} \mathrm{C}$, facial erythema, and arthralgia. Clinical data showed Coombs's test 4+, leucopenia, raised ESR, low complement, and proteinuria $3+$. Histological examination of his kidney under light microscope showed proliferative glomerulonephritis. MII on admission was $61 \%$ Prednisone $100 \mathrm{mg}$ once daily was started and during the following month on steroids clinical and laboratory data quickly returned to normal as did MII titres.

MIT AND RENAL INVOLVEMENT IN SLE

The mean MII of SLE patients with proteinuria* and/or granular casts $(70 \cdot 3 \% \pm 18 \cdot 2)$ was significantly lower than that of patients with normal urinalysis $(89.3 \% \pm 15 \cdot 7)(\mathrm{P}<0.01$, Fig. 4). For those patients whose MIT and urinalysis were repeated two or more times, only the highest and lowest MII titres were considered in order to minimize sampling error.

Kidney biopsy was performed on 22 SLE patients, and in 16 it was done within a week of MII esti-

*Trace proteinuria was not taken as significant proteinuria and was therefore grouped together with no proteinuria.

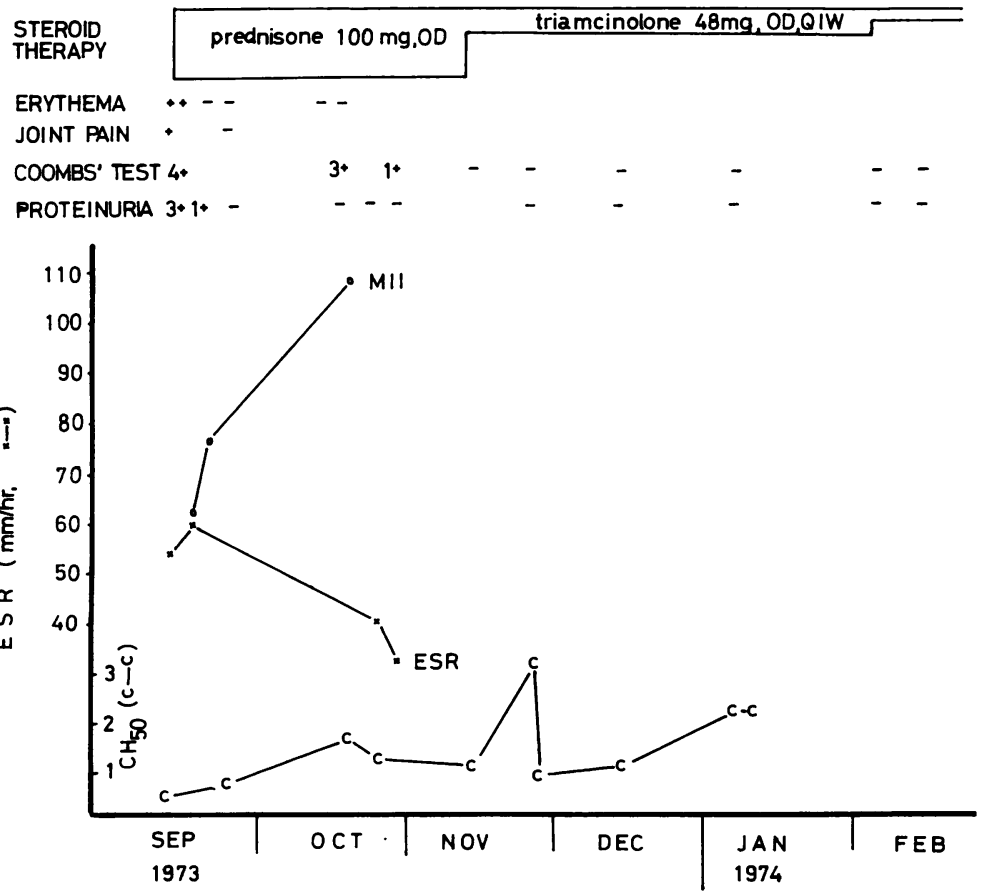

Fig. 3 Case 8. Migration inhibition test with DNA as antigen and clinical course of $a$ patient with SLE. 


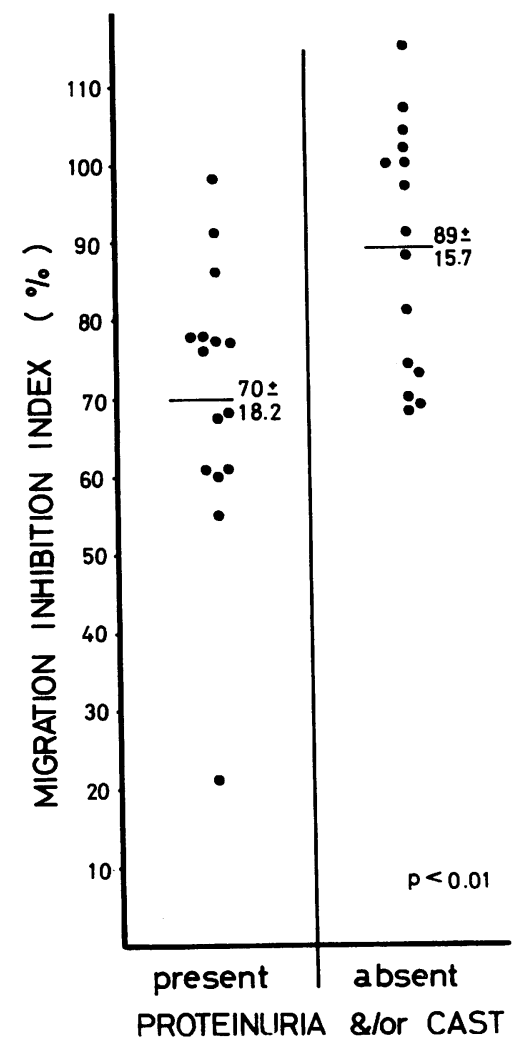

Fig. 4 Migration inhibition test with DNA as antigen and proteinuria and/or granular casts in patients with SLE. mations (Table 3). All 6 MIT-positive patien showed fluorescent staining by immunohistology. In 5 staining was moderate to strong, and in the remaining patient weak. In the 10 MIT-negative patients fluorescence was negative in 1 , weak in $\frac{\mathscr{5}}{5}$, strong in 3 , and the remaining case was not studied by this method.

\section{EFFECT OF STEROID THERAPY ON THE MIT \&}

No overall correlation was observed between MH titres and duration or dosage of steroids. The MH of one patient (Case 14, Table 1) who followedca downhill course clinically was negative, but becange positive despite a high dose of prednisone. In 2 other cases (Cases 8, 17, Table 1), whose clinicsy courses were smooth, the MII became negative after massive steroid therapy.

The results of the MIT with RNA as antigen were analysed in 7 SLE patients and 14 control subjects (10 normals and 4 patients with othet diseases), as shown in Tables 1 and 2. Although क्षि the tests were essentially negative with the mean MII being $92 \% \pm 7 \cdot 4$ for SLE, $108 \% \pm 17$ 의 for normals, and $92 \% \pm 12.4$ for patients with other diseases, respectively, the difference in means between SLE and normal was significant $(P<0 \cdot 05)^{\text {. }}$. The results of the MIT with ENA in 5 SLE patients and 3 normal controls were all negative (Tables 1,

\section{Discussion}

Since Søborg and Bendixen (1967) first established the MIT as the simplified modification of the

Table 3 Migration inhibition index (MII) and renal histology in patients with SLE

\begin{tabular}{|c|c|c|c|c|c|c|}
\hline \multirow{3}{*}{$\begin{array}{l}\text { Case } \\
\text { no. }\end{array}$} & \multirow{3}{*}{$\begin{array}{l}M I I / D N A \\
200 \mu \mathrm{g} / \mathrm{ml} \\
(\%)\end{array}$} & \multicolumn{5}{|l|}{ Renal histology } \\
\hline & & \multirow[t]{2}{*}{ Light microscopy } & \multirow[t]{2}{*}{ Immunofluorescence } & \multicolumn{3}{|c|}{ Electron microscopy } \\
\hline & & & & $\begin{array}{l}\text { Subendo- } \\
\text { thelial } \\
\text { deposit }\end{array}$ & $\begin{array}{l}\text { Intra- } \\
\text { mesan- } \\
\text { mesangial deposit }\end{array}$ & $\begin{array}{l}\text { Virus } \\
\text { like } \\
\text { partien }\end{array}$ \\
\hline \multicolumn{7}{|c|}{ MIT-positive patients } \\
\hline 3 & 61 & Diffuse proliferative & $2+$ & - & + & - \\
\hline 4 & 67 & & $1+$ & & & \\
\hline 6 & 21 & Proliferative & $\begin{array}{l}3+ \\
\text { membranous }\end{array}$ & & & \\
\hline 9 & 55 & $\begin{array}{l}\text { Mild increase } \\
\text { in mesangium }\end{array}$ & $2+$ & - & - & - \\
\hline 11 & 61 & $\begin{array}{l}\text { Mild proliferative } \\
+ \text { mesangial }\end{array}$ & $3+$ & - & - & - \\
\hline 17 & 68 & Proliferative & $3+$ & & & \\
\hline \multicolumn{7}{|c|}{ MIT-negative patients } \\
\hline 7 & 88 & & $1+$ & & & \\
\hline 8 & 107 & Proliferative & & & & \\
\hline 10 & 77 & Proliferative & $1+$ & & & \\
\hline 13 & 100 & $\begin{array}{l}\text { Minimal increase } \\
\text { in mesangium }\end{array}$ & $1+$ & & & \\
\hline 14 & 91 & Focal proliferative & $3+$ & - & + & - \\
\hline 18 & 90 & Proliferative & $1+$ & & & \\
\hline 20 & 100 & & $3+$ & & & \\
\hline 21 & 98 & Subendotherial & $1+$ & - & - & - \\
\hline 24 & 102 & Mesangial & $3+$ & - & - & + \\
\hline 26 & 113 & Proliferative & - & - & - & - \\
\hline
\end{tabular}


macrophage migration inhibition test, this assay system has been successfully used by many using particulate antigens (Søborg, 1967). When the soluble antigens were in use their validity was doubted (Lockshin, 1969; Kaltreider et al., 1969). Kaltreider et al. (1969) tried to find the correlation between the MIT and the results of skin tests using tuberculin PPD as the antigen. Later, Rosenberg and David (1970) re-evaluated and confirmed the validity of the MIT with PPD, ascribing prior failures to technical problems. We also reconfirmed this point using the same model. MIT correlated well with the skin test, using tuberculin PPD as antigen (Fig. 1, Tables 1,2).

The involvement of humoral-type immunity in SLE has been extensively studied and its pathogenetic role well documented, e.g. detection of antinuclear antibodies and/or free DNA in patients' sera (Seligmann, 1957; Deicher et al., 1959; Holman et al., 1959; Stollar et al., 1962; Tan et al., 1966; Pincus et al., 1969; Hughes, 1971; Harbeck et al., 1973), a lowered level of serum complement (Lange et al., 1960; Lagrue et al., 1966; Asano et al., 1968), and the demonstration of DNA-anti-DNA antibody complex together with complement in glomeruli (McCluskey et al., 1966; Lange et al., 1966; Koffler et al., 1967), etc. On the other hand, fewer studies have been done on cell-mediated immunity and its role in the disease process is still controversial.

With regard to the hypersensitivity to DNA, since our report (Ores and Lange, 1964) on positive skin tests to DNA, Patrucco et al. (1967) published their results on a blast-like transformation of lymphocytes cultured in vitro with calf thymus DNA. A similar report was published independently by one of us (Okubo, 1968). Podleski and Podleski (1973) observed in vitro specific cytotoxic effects of lymphocytes from SLE against DNA-coated human cells. Recently, Abe et al. (1973) reported that the migration inhibition factor was produced by incubating lymphocytes taken from SLE patients with calf thymus DNA. Similar positive results were reported by Galanaud et al. (1971), Dormont et al. (1972), Moulias et al. (1972), using a Bendixentype direct MIT. Our study, using the same direct MIT, gave positive results in $65.3 \%$ of SLE patients, using double-stranded calf thymus DNA as antigen (Fig. 2, Table 1). In the control subjects the MII was negative except in 2 cases (Cases 28, 40). In agreement with the observations of Moulias et al. (1972) and Dormont et al. (1972), no correlation was found between the MIT and other clinical or laboratory data of SLE excepting nephropathy (see below).

However, other workers reported negative results using similar methods, e.g. Reinert et al. (1971) (lymphocyte transformation test), Horwitz (1972) (skin test and lymphocyte culture in vitro), Dormont et al. (1972) (lymphocyte transformation test, although results by MIT were positive), Hahn et al. (1973a, b) (skin test and lymphocyte culture in vitro), Federlin and Helmke (1972) (migration inhibition test).

In order to understand the discrepancies many factors have to be considered, such as differences in the techniques used, consequently, the different aspects studied (skin test, lymphoblastogenesis, or migration inhibition factor), the effect of steroid or other immunosuppressive therapy, and most importantly the presence of disturbed or deficient cellular immunity in SLE (Bitter et al., 1971; Horwitz, 1972; Federlin and Helmke, 1972; Williams et al., 1973; Messner et al., 1973). Steroid therapy, in agreement with previous reports, did not seem to affect profoundly the lymphocytic reactivity in vitro. In one patient (Case 14) the migration inhibition became apparent only after initiation of steroid therapy, while in 2 other patients (Cases 8,17 ) no further inhibition was observed during steroid administration. Our result seemed related more to the disease activity itself than to dosage or duration of steroid therapy.

That disturbed cell-mediated immunity occurs in SLE has long been suggested by frequent falsenegative skin tests with tuberculin antigen. Bitter $e t$ al. (1971) and Horwitz (1972) observed a depressed intradermal reaction to prevalent bacterial or fungal antigens in their SLE patients. As for the stimulation study by phytohaemagglutinin, Bitter $e t$ al. (1971) could not produce a stimulation response, while Horwitz (1972) found a normal response. Using the MIT, Federlin and Helmke (1972) showed depressed cellular hypersensitivity to DNA in SLE, while Williams et al. (1973) and Messner et al. (1973) reported a decrease in the number of $T$ lymphocytes in the peripheral blood of SLE patients. In one of our cases (Case 2) the MII with PPD as antigen fluctuated from 63 to $132 \%$, possibly suggesting that deranged cellular immunity may affect the MII titre.

Recently it has been suggested that cell-mediated immunity may play a role in the development of lupus nephropathy (Goldman et al., 1972; Abe et al., 1973). Goldman et al. (1972) reported that 3 of 6 SLE patients with active nephritis showed a positive response to rabbit native DNA when lymphocytes were cultured in vitro. All 10 SLE patients with the nephrotic syndrome studied by Abe et al. (1973) showed a positive migration inhibition factor sometime during the clinical course. Abe et al. further referred to the possible role of cell-mediated immunity in the perpetuation of renal disease.

Our results were compatible with previous data in that the MIT was positively correlated with the 
presence of proteinuria and/or granular casts in the urinary sediment. We performed kidney biopsies in 22 of our 26 SLE patients, aiming for prompt diagnosis and treatment of their renal disease. In 16 of these 22 patients the MIT was performed simultaneously (Table 3 ). MIT-positive patients showed active immunohistology as seen by positive staining with FITC-labelled antihuman IgG and antihuman $\beta_{1} \mathrm{c}$ globulin $(2+$ to $3+$ staining in 5 of 6 MIT-positive patients, Table 3). Also in 3 out of 10 MIT-negative paiients (Cases 14, 20, 24, 'Table $3), 3+$ siaining was observed. This may have something to do with derangement of cell-mediated immunity inherent in SLE, and perhaps some patients with very active lupus nephropathy have no more $T$ lymphocytes left in their circulation responsible for the positive MIT. Further investigation, including studies of $\mathrm{T}$ and $\mathrm{B}$ lymphocytes circulating in peripheral blood of SLE patients with active immunohistology at the time of the MIT study, may be necessary to clarify the role of cellular immunity in the renal disease of SLE.

Part of this study was presented at the annual meeting of the American Federation for Clinical Research, May 1974, Atlantic City, N.J.

\section{References}

Abe, T., Hara, M., Yamasaki, K., and Homma, M. (1973). Cell-mediated immune response in systemic lupus erythematosus. In vitro cellular response to native DNA by macrophage inhibitory test. Arthritis and Rheumatism, 16, 688-694.

Asano, S., Marumo, K., Igaki, Y., Toyoizumi, E., Okubo, M., Tamura, T., Kurata, K., and Kawai, K. (1968). Serum complement in systemic lupus erythematosus (SLE). Japanese Journal of Allergy (Tokyo), 17, 597-609.

Bitter, T., Bitter, F., Silberschmidt, R., and Dubois, E. (1971). In vivo and in vitro study of cell-mediated immunity (CMI) during the onset of systemic lupus erythematosus. Arthritis and Rheumatism, 14, 152-153.

Cohen, A. S., Reynolds, W. E., Franklin, E. C., Kulka, J. P., Ropes, M. W., Shulman, L. E., and Wallace, S. L. (1971). Preliminary criteria for the classification of systemic lupus erythematosus. Bulletin on Rheumatic Diseases, 21, 643648.

Deicher, H. R., Holman, H. R., and Kunkel, H. G. (1959). The precipitation reaction between DNA and a serum factor in systemic lupus erythematosus. Journal of Experimental Medicine, 109, 97-114.

Dormont, J., Sobel, A., Galanaud, P., Boelaert, J., Mery, J. Ph., and Richet, G. (1972). Exploration de l'immunité cellulaire au cours du lupus érythémateux disséminé. Journal d'Urologie et Néphrologie, 78, 980-987.

Federlin, K., and Helmke, K. (1972). Depression of cellular hypersensitivity to DNA in systemic lupus erythematosus. Lancet, 1, 596-597.

Galanaud, P., Dormont, J., Crosnier, J., and Mery, J. Ph. (1971). Leucocyte migration test in sero-negative SLE. Lancet, 2, 923.

Goldman, J. A., Litwin, A., Adams, L. E., Krueger, R. C., and Hess, E. V. (1972). Cellular immunity to nuclear antigens in systemic lupus erythematosus. Journal of Clinical Investigation, 51, 2669-2677.
Hahn, B. H., Bagby, M. K., and Osterland, C. K. (1973\&. Disparity between humoral and cellular immune responses to desoxyribonucleic acid in systemic lupus erythematos American Journal of the Medical Sciences, 266, 193-201.5?

Hahn, B. H., Bagby, M. K., and Osterland, C. K. (1973耳. Abnormalities of delayed hypersensitivity in systenoc lupus erythematosus. American Journal of Medicine, 25-31.

Harbeck, R. J., Bardana, E. J., Kohler, P. F., and Carr, R.̊. (1973). DNA: anti-DNA complexes: their detection fh systemic lupus erythematosus sera. Journal of Clinical Investigation, 52, 789-795.

Hargraves, M. M., Richmond, H., and Morton, R. (1948). Presentation of two bone marrow elements: 'tart' cell and the 'LE' cell. Proceedings of the Staff Meetings of the Mayn Clinic, 23, 25-28.

Holman, H. R., Deicher, H. R. G., and Kunkel, H. G. (195? The LE cell and LE serum factor. Bulletin of the New Yogk Academy of Medicine, 35, 409-418.

Horwitz, D. A. (1972). Impaired delayed hypersensitivity systemic lupus erythematosus. Arthritis and Rheumatis 600 , 15, 353-359.

Hughes, G. R. (1971). Significance of anti-DNA antibodies in systemic lupus erythematosus. Lancet, 2, 861-863.

Kaltreider, H. B., Soghor, D., Taylor, J. B., and Deckê, J. L. (1969). Capillary tube migration for detection $8 \mathrm{f}$ human delayed hypersensitivity: difficulties encounteread with 'buffy coat' cell, and tuberculin antigen. Journal of Immunology, 103, 179-184.

Kay, E. R., Simmons, N. S., and Dounce, A. L. (1952). An improved preparation of sodium desoxyribonucleate. Journal of the American Chemical Society, 74, 1724-1726.

Koffler, D., Schur, P. H., and Kunkel, H. G. (1967). I munological studies concerning the nephritis of systenge lupus erythematosus. Journal of Experimental Medicing, 126, 607-623.

Lagrue, G., Bariéty, J., Halpern, B., and Milliez, P. (196Q). Le complément sérique dans les néphropathies. Bulletïs et Mémoires de la Société Medicale des Hôpitaux de Parḩ, 117, 985-996.

Lange, K., Wasserman, E., and Slobody, L. B. (1960). T声 significance of serum complement levels for the diagnosis and prognosis of acute and subacute glomerulonephrinis and lupus erythematosus disseminatus. Annals of Internal Medicine, 53, 636-646.

Lange, K., Treser, G., Sagel, I., Ty, A., and Wasserman, (1966). Routine immunohistology in renal disease8. Annals of Internal Medicine, 64, 25-40.

Lockshin, M. D. (1969). Failure to demonstrate leucocyte migration inhibition in human tuberculin hypersensitivi Proceedings of the Society for Experimental Biology and Medicine, 132, 928-930.

Lowry, O. H., Rosebrough, N. J., Farr, A. L., and Randa7t; R. J. (1951). Protein measurement with the Folin pher(S) reagent. Journal of Biological Chemistry, 193, 265-275.

McCluskey, R. T., Vassalli, P., Gallo, G., and Baldw D. S. (1966). An immunofluorescent study of pathogentif mechanisms in glomerular diseases. New England Journgl of Medicine, 274, 695-701.

Messner, R. P., Lindström, F. D., and Williams, R. C., $\mathbf{W}$. (1973). Peripheral blood lymphocyte cell surface marke्कs during the course of systemic lupus erythematosus. Journal of Clinical Investigation, 52, 3046-3056.

Moulias, R., Goust, J. M., Reinert, Ph., Devillechabroll, A., Muller Berat, C. N., Hereman, C., and Godeau, (1972). Le test de migration en présence d'ADN d\&s leucocytes au cours du lupus érythémateux dissémint: Nouvelle Presse Médicale, 1, 1403-1407. 
Okubo, M. (1968). In vitro response of peripheral lymphocytes from patients with systemic lupus erythematosus to DNA. (In Japanese.) Journal of Japanese Society of Internal Medicine (Tokyo), 57, 758-770.

Ores, R. O., and Lange, K. (1964). Skin test for the diagnosis of systemic lupus erythematosus. American Journal of the Medical Sciences, 248, 562-566.

Patrucco, A., Rothfield, N. F., and Hirschhorn, K. (1967). The response of cultured lymphocytes from patients with systemic lupus erythematosus to [.NA. Arthritis and Rheumatism, 10, 32-37.

Pincus, T., Schur, P. H., Rose, J. A., Decker, J. L., and Talal, N. (1969). Measurement of serum DNA-binding activity in systemic lupus erythematosus. New England Journal of Medicine, 281, 701-705.

Podleski, W. K., and Podleski, U. G. (1973). Circulating sensitized lymphocytes in systemic lupus erythematosus. Nature, 241, 278-279.

Reinert, Ph., Devillechabrolle, A., Bribet-Forette, F. Chigot, D., and Moulias, R. (1971). Le test de transformation blastique des lymphocytes (TTL) appliqué au diagnostic des affections auto-immunes. Premier résultats en présence d'antigènes thyroidiens et d'ADN Presse Médicale, 79, 1279-1281.

Riggs, J. L. L.ob, P. C., and Fveland, W. C (1960). A simple fractionation method for preparation of fluoresceinlaballed gamma globulin. Proceedings of the Society for Experimental Biology and Medicine, 105, 655-658.

Rosenberg, S. A., and David, J. R. (1970). Inhibition of leukocyte migration: an evaluation of this in vitro assay of delayed hypersensitivity in man to a soluble antigen. Journal of Immunology, 105, 1447-1452.

Seligmann, M. (1957). Mise en évidence dans le sérum des malades atteints de lupus erythémateux disséminé d'une substance déterminant une réaction de précipitation avec l'acide désoxy-ribonucléique. Comptes Rendus Heb- domadaires des Séances de Y Académie des Sciences, 245, 243-245.

Sharp, G. C., Irvin, W. S., Laroque, R. L., Velez, C., Daly, V., Kaiser, A. D., and Holman, H. R. (1971). Association of auto-antibodies to different nuclear antigens with clinical patterns of rheumatic disease and responsiveness to therapy. Journal of Clinical Investigation, 50, 350-359.

Sharp, G. C., Irvin, W. S., Tan, E. M., Gould, R. G., and Holman, H. R. (1972). Mixed connective tissue diseasean apparently distinct rheumatic disease syndrome associated with a specific antibody to an extractable nuclear antigen (ENA). American Journal of Medicine, 52, 148-159.

Sober, H. A., Gutter, F. J., Wyckoff, M. M., and Peterson, E. A. (1956). Chromatography of proteins. II. Fractionation of serum protein on anion exchange cellulose. Journal of the American Chemical Society, 78, 756-763.

Søborg, M. (1967). In vitro detection of cellular hypersensitivity in man. Specific migration inhibition of white blood cells from Brucella-positive persons. Acta Medica Scandinavica, 182, 167-174.

Søborg, M., and Bendixen, G. (1967). Human lymphocyte migration as a parameter of delayed hypersensitivity. Acta Medica Scandinavica, 181, 247-256.

Stollar, D., Levine, L., and Marmur, J. (1962). Antibodies to denatured deoxyribonucleic acid in lupus erythematosus serum. II. Characterization of antibodies in several sera. Biochimica et Biophysica Acta, 61, 7-18.

Tan, E. M., Schur, P. H., Carr, R. I., and Kunkel, H. G. (1966). Deoxyribonucleic acic (DNA) anc antibodies to DNA in the serum of patients with systemic lupus erythematosus. Journal of Clinical Investigation, 45, 1732-1740.

Williams, R. C., Jr., Deboard, J. R., Mellbye, O. J., Messner, R. P., and Lindström, F. D. (1973). Studies of T- and Blymphocytes in patients with connective tissue diseases. Journal of Clinical Investigation, 52, 283-295. 